\title{
Effect of Integrated Nutrient Management on Nutrient concentration and Uptake in Grafted Tomato
}

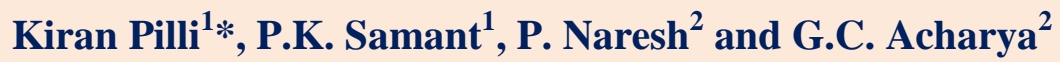 \\ ${ }^{1}$ Department of Soil Science and Agricultural Chemistry, College of Agriculture, \\ OUAT, Bhubaneswar-751003, India \\ ${ }^{2}$ Central Horticultural Experiment Station, Aiginia, Bhubaneswar-751003, India \\ *Corresponding author
}

\begin{abstract}
Keywords
Integrated Nutrient

Management,

Grafting, Organic

and Inorganic

Nitrogen, Nutrient

concentration and

uptake

Article Info

Accepted:

12 January 2019

Available Online:

10 February 2019 nutrient concentration and uptake of Grafted tomato during 2017-2018 at Central Horticultural Experiment Station (Aiginia), Bhubaneswar with inorganic and organic nutrient sources. The experimental results of grafted tomato with INM package showed that Nutrient content of fruit was higher in non-grafted tomato than grafted tomatoes. Whereas, in harvested plant sample nutrient content was higher in grafted tomato. Irrespective of grafting method, the treatment $100 \%$ inorganic nitrogen showed highest $\mathrm{N}$ and $\mathrm{K}$ concentration and uptake compared to $100 \%$ organic nitrogen and combination of organic and inorganic nitrogen treatments. Whereas the treatment $100 \%$ organic nitrogen showed highest $\mathrm{Ca}, \mathrm{Mg}$ and $\mathrm{S}$ uptake and concentration compared to $100 \%$ organic nitrogen. But $\mathrm{P}$ concentration and uptake was highest in combination of inorganic and organic treatments. Overall, the grafted tomato has shown highest nutrient concentration and uptake compared to non-grafted tomato, often been attributed to the difference in root morphology and root characteristics including lateral and vertical development of roots, root length, density and number of root hairs which played an active role in nutrient uptake. Crop had harvested more amounts of nutrients from soil for growth and yield.
\end{abstract}

\section{A B S T R A C T}

An experiment was conducted to find out the effect of integrated nutrient management on

\section{Introduction}

Grafting is an art and technique in which two living parts of different plants or same plant are joined together in a manner that they would unite together and subsequently grow into a composite plant. In addition to breeding of resistant cultivars, integrated pest management practices have been developed out of which grafting technique has been successfully used for controlling several soilborne diseases and damage caused by rootknot nematodes in tomato production especially under intensive cultivation (Lee et al., 2010; Rivard et al., 2010a). The main purpose of employing grafting technology is to control soil borne diseases. However, the impact of grafting includes not only a stronger resistance against pathogens but also a higher tolerance to abiotic stress conditions such as 
salinity, heavy metal, nutrient stress, thermal stress, water stress, organic pollutants, alkalinity and could improve fruit quality. (Crino et al., 2007; Lee et al., 2010; Rouphael et al., 2008b and Proietti et al., 2008).Grafting imprints resistance to pathogenic agents, soil pests, tolerance to abiotic stress factors, improves water and nutrient absorption and increases the graft vigour (King et al., 2010; Lee, 1994).

Plant growth and development largely depend on the combination and concentration of mineral nutrients available in the soil. Plants often face significant challenges in obtaining an adequate supply of plant nutrients to meet the demands of basic cellular processes due to their relative immobility. Changes in the climate and atmosphere can have serious effects on plants, including changes in the availability of certain nutrients.

The use and appropriate management of organic fertilizers and can reduce the need for chemical fertilizers thus allowing the small farmers to reduce cost of production and management of soil health. The release pattern of inorganic nutrients from fertilizer sources is higher as compared to organic source. As a result of which released nutrients are either used or lost rapidly by different means. On the other hand, organic fertilizers are mineralized slowly and nutrients become available for a longer period of time as a result of which soil nutrient status is maintained till the harvest of the crop.Organic manures having humic substances not only improve soil fertility by modifying soil physical and chemical properties (Asiket al., 2009), (Heitkamp et al., 2011) but also improves the moisture holding capacity of the soil, ultimately enhanced productivity and quality of crop produce. Several studies also reported that vermicompost application suppresses infection by insect pests, repel crop pests and induce biological resistance in plants due to the presence of antibiotics and actinomycetes (Munroe, 2007). Use of vermicompost in horticulture at large scale can solve the management and disposal problem associated with macrophytes and also resolves the deficiency of organic matter in addition to nutrient depletion (Najar and Khan, 2013).

\section{Materials and Methods}

\section{Poly pot preparation and treatments}

The experiment was conducted in Central Horticultural Experiment Station (Aiginia), Bhubaneswar with Grafted Tomato (Brinjal root stock and tomato scion), Non-Grafted Tomato, Self-Grafted Tomato during 2017-18 in a Completely Randomized Design with six treatments and each treatment was replicated thrice. Each ploy bag was filled with $15 \mathrm{~kg}$ soil. Seed treatment was done with Bavistin @ $2 \mathrm{gm} \mathrm{kg}^{-1}$ of seed and Chlorodust was applied @ 1 g/pot against termite. Grafted Tomatoes (BT-10 grafted on brinjal var. UtkalAnushree), non-grafted and self-grafted tomatoes were evaluated with six treatments and each treatment replicated trice.

\section{Grafting}

In Grafted Tomato Utkal Kumari (BT-10) scion were grafted onto the Utkal Anushree (brinjal var.) rootstock using "side grafting" and in Self Grafted Tomato Utkal Kumari (BT-10) scion were grafted onto the Utkal Kumari (BT-10) rootstock using "side grafting”. Non-grafted seedlings were used directly. Grafting was carried out in moist chambers at 2-3 leaf stage (20-25 days) of scion seedlings and 3-4 leaf stage (55-60 days) of root stock. Grafting was made with similar thickness of scion and root stock which was cut at $45^{\circ}$ and joined by using plastic clips. The grafted plants were transplanted after thirty-five days after 
sowing. Then they were exposed to water stress before being taken to moisture chambers. This process was carried out to ensure high grafting success. The grafted seedlings were transferred to humidified chambers with a relative humidity of $85-95$ per cent for five days to allow the graft union to heal, then intensity of light was gradually increased with decrease and relative humidity. Then the seedlings were transferred to the normal nursery where healing process was continued for two weeks before they were transplanted. Plants were grown under natural light conditions.

\section{Collection and processing of plant samples}

For determination of nutrient content, plant samples were collected at harveststage and fruit sample were collected in mid picking. Five plants from each treatment were selected randomly. After washing with distilled water and the samples were allowed for sun drying in the oven at $75^{\circ} \mathrm{C}$ temperature till constant weight was obtained. The fruits were collected from each treatment and kept in the moisture box for moisture content by cutting it into half in moisture box and kept for oven drying. A $2.5 \mathrm{~g}$ fresh fruit sample was taken for nutrient analysis.

\section{Analysis of plant samples}

\section{Nitrogen}

Kjeldahl digestion followed by distillation method as described in AOAC (1960)

Phosphorus (P), Potash (K), Calcium (Ca), Magnesium(Mg), and Sulphur (S)

The sample are to be digested in di-acid mixture $\left(\mathrm{HNO}_{3}: \mathrm{HClO}_{4}=3: 2\right)$. The $\mathrm{P}$ and $\mathrm{S}$ are estimated by spectrophotometrically, the K by flame photo meter, and $\mathrm{Ca}$ and $\mathrm{Mg}$ by EDTA titration method (Page et al., 1982).

\section{Statistical analysis}

The experimental data pertaining to biometric observations, nutrient concentration, nutrient uptake were recorded, compiled in appropriate tables and analyzed statistically as per the procedure appropriate to the design (Gomez and Gomez 1976). All the data were statistically analyzed by two-factorial CRD ANOVA.

\section{Empirical formulae for nutrient uptake}

Nutrient uptake $\left(\mathrm{Kg} \mathrm{ha}^{-1}\right)$ :

Nutrient conc. $(\%) \times$ Dry matter $\left(\mathrm{kg} \mathrm{ha}^{-1}\right)$ 100

\section{Results and Discussion}

The influence of integrated nutrient management practices on yield and nutrient accumulation and acquisitionof grafted tomato crop was studied, where the crop received soil test based recommended dose (200:156:125 N: $\mathrm{P}_{2} \mathrm{O}_{5}: \mathrm{K}_{2} \mathrm{O} \quad \mathrm{Kg} \quad \mathrm{ha}^{-1}$ ) of inorganic nutrients and organic nutrients, either alone or in integration. The soil was ameliorated with calcium carbonate @ 0.2 LR.

Influence of INM practices of grafted tomato on nutrient concentration in fruit sample, post-harvest sample and Total Nutrient uptake

\section{Nitrogen}

The highest nitrogen content of fruit $(4.30 \%)$, plant sample $(3.09 \%)$ and Total Nitrogen Uptake (4.13 $\mathrm{g} \mathrm{pot}^{-1}$ ) in was observed in $\mathrm{T}_{2}$ which was significantly higher than control. The Total Nitrogen Uptake treatments in $T_{2}$ were found to be statistically on par with $\mathrm{T}_{3}$ and $\mathrm{T}_{4}$ (Table 1). However, nitrogen content in fruit sample, plant sample and total 
nitrogen was increased with incremental proportion of inorganic nitrogen. It may be due to immobilisation of nitrogen in organic applied treatments. Lynch et al., 2004 reported that after application of higher dose of organic fertilizer, nitrogen immobilization was happened in the first crop season followed by mineralization during the second crop.

Out of three types of grafted tomatoes, nongrafted tomato recorded significantly highest nitrogen content $(4.70 \%)$ in fruit, it was found to be 72.2 per cent and 78.0 per cent more than Grafted (2.73\%) and self-grafted tomato (2.64 \%) respectively. It may be due to dilution of nitrogen concentration in grafted tomato by producing high yield (g/plant). Whereas, in plant Grafted tomato recorded highest content of nitrogen $(2.60 \%)$ which was 3.2 per cent and 4 per cent more than non-grafted tomato $(2.52 \%)$ and self-grafted tomato $(2.50 \%)$ respectively. Regarding total $\mathrm{N}$ uptake by plant the self-grafted tomato (2.34 $\left.\mathrm{g} \mathrm{pot}^{-1}\right)$ was 34 per cent inferior, and Grafted tomato (4.83 $\mathrm{g} \mathrm{pot}^{-1}$ ) was 36.0 per cent better performer for nitrogen uptake compared to non-grafted tomato (3.56 g pot $\left.{ }^{-1}\right)$.

\section{Phosphorus}

The INM packages resulted in highest content of phosphorus in $\mathrm{T}_{4}$ in fruit $(0.43 \%)$, plant $(0.21 \%)$ and total $\mathrm{P}$ uptake $\left(0.53 \mathrm{~g} \mathrm{pot}^{-1}\right)$ which were significant to the control (Table 2). Treatments $T_{3}$ and $T_{5}$ are at par with $T_{4}$ in all the cases. The result observed implies that $P$ concentration and uptake was influenced by the integrated use of Inorganic and organics. It may be due to the experimental soil was acidic in nature which has property of $\mathrm{P}$ fixation, by application of organics to soils the microbial population increases in soil which have been responsible to increase the availability of $\mathrm{P}$ in soil by producing organic acids (Verma and Rawat, 1999). Unlike N, P is strongly absorbed by soils. As a result, most soils contain abundant amount of $\mathrm{P}$, as it hardly leaches out of the soil profile. Because tomatoes take up relatively smaller amount of $\mathrm{P}$ than the amounts of $\mathrm{N}$ and $\mathrm{K}$, the concentration of $\mathrm{P}$ in tomato is also smaller. The results were supported by Ghosh et al., (2014) and Azam et al., (2013) that the integration of organic fertilizers along with synthetic fertilizers results into highest $\mathrm{P}$ uptake by plants.

Out of three types of grafted tomatoes, nongrafted and self-grafted tomato recorded higher content of phosphorus $(0.38 \%)$ which was 3.0 per cent more than Grafted tomato $(0.37 \%)$. Whereas, Grafted tomato and selfgrafted tomatoes recorded highest content of phosphorus $(0.20 \%)$ which was 17.6 per cent more than non-grafted tomato $(0.17 \%)$ in post-harvest plant sample. There was significant interaction between the fertilization treatments and grafting methods. The total P uptake was significantly highest in Grafted tomato compared to others. The Grafted tomato removed double the amount of $\mathrm{P}$ than other two.

\section{Potassium}

The INM packages maintained significantly higher concentration of $\mathrm{K}$ than control. Higher $\mathrm{K}$ concentration was recorded with $\mathrm{T}_{2}$ in fruit $(2.90 \%)$, plant $(2.72 \%)$ and total $\mathrm{K}$ uptake (3.44 g pot $\left.{ }^{-1}\right)$ (Table 3). The concentration of $\mathrm{K}$ in Fruit of tomato was at par with each other, but showed significant difference in plant. Where as in total $\mathrm{K}$ uptake was highest in $T_{2}$ and it was on par with $T_{3}$ and $\mathrm{T}_{5}$. However, potassium content in fruit sample, plant sample and total nitrogen was increased with incremental proportion of inorganic nitrogen. As like as with nitrogen, potassium is also absorbed by tomato in large amount because it is not fixed in acid soil. 
These observations indicate that tomato responded quite well to inorganic fertilization than combinations of inorganic and organic fertilization or organic fertilization only. But this was contrary to the general notion that inorganic and organic fertilization is better than inorganic fertilization only. Probably, the contradiction here could be due to nutrient imbalance. Pyo et al., (2010) reported that low affinity transport systems generally function when potassium levels in the soil are adequate for plant growth and development. This process is mediated by ion channels in the plasma membrane of root cells, allowing passive transport of $\mathrm{K}^{+}$from areas of relatively high external concentration into the plant cells where the concentration of $\mathrm{K}^{+}$is lower. The expression of these low affinity transporters does not appear to be significantly affected by potassium availability.

In fruit out of three types of grafted tomatoes, non-grafted tomato $(2.76 \%)$ maintained significantly higher mean concentration of $\mathrm{K}$ than self-grafted tomato $(2.66 \%)$ and Grafted tomato $(2.44 \%)$. Where as in plant, grafted tomato recorded highest content of potassium $(2.80 \%)$ and showed 70.70 per cent and 46.60 per cent more than Grafted tomato $(1.91 \%)$ and self-grafted tomato (1.64\%) respectively. The total $\mathrm{K}$ uptake by grafted tomato showed highest potassium uptake (3.98 $\mathrm{g} \mathrm{pot}^{-1}$ ) which was significantly higher than non-grafted (2.63 $\left.\mathrm{g} \mathrm{pot}^{-1}\right)$ and selfgrafted tomato $\left(2.24 \mathrm{~g} \mathrm{pot}^{-1}\right)$. Grafted tomato showed 51 per cent better K uptake over nongrafted. The self-grafted tomato was 15 per cent less compared to non-grafted tomato.

\section{Calcium and magnesium}

The INM packages resulted in highest content of Calcium and Magnesium in $\mathrm{T}_{6}$ in fruit $(1.19 \%)(0.83 \%)$ and in plant $(2.80 \%)(1.25$ $\%)$ respectively which were significantly higher than control. For both $\mathrm{Ca}$ and $\mathrm{Mg}$ concentrations in plant INM packages showed significant difference, where as in fruit $\mathrm{T}_{5}$ and $\mathrm{T}_{4}$ are found to be on par with $\mathrm{T}_{6}$. The results showed that $\mathrm{Ca}$ and $\mathrm{Mg}$ concentration and uptake was decreasing with incremental proportion of inorganic nutrients (Table 4 and 5). Nutrients, such as $\mathrm{Ca}$ and $\mathrm{Mg}$, are applied when liming is done in acidic soils. The organic substances and lime acted catalytically giving better results. The lime had created conducive soil environment for making the nutrients available to the plants and helped in its absorption. The presence of organic nutrient supplements like farm yard manure or vermicompost had created optimum microbial activities. Thereby the soil under different treatments enriched with all required nutrients and with enhanced the root activities for better nutrient absorption. Organic amendments may increase supply of macro and micro -nutrients to plants and could mobilize unavailable nutrients to available form, and as a cumulative effect, uptake is higher than synthetic fertilizers. Similar results are supported by Kachot et al., 2001.

Out of three types of grafted tomatoes, nongrafted tomato recorded highest content of Caand $\mathrm{Mg}(1.10 \%)(0.71 \%)$ than that of Grafted $(1.04 \%)(0.56 \%)$ and self-grafted tomato $(0.66 \%)(0.50 \%)$ respectively. But, in plant grafted tomato recorded highest content of $\mathrm{Ca}$ and $\mathrm{Mg}(2.70 \%)(0.84 \%)$ than that of non-grafted $(2.50 \%)(0.74 \%)$ and selfgrafted tomato $(2.11 \%) \quad(0.54 \%)$ respectively. Total calcium uptake $(2.34 \mathrm{~g}$ pot $^{-1}$ ) which was significantly higher than non-grafted $\left(1.51 \mathrm{~g} \mathrm{pot}^{-1}\right)$ and self-grafted tomato $\left(1.50 \mathrm{~g} \mathrm{pot}^{-1}\right)$. The Grafted tomato showed 54.0 per cent and 52.0 per cent more calcium uptake over non-grafted and selfgrafted tomatoes respectively. Grafted tomato removed high magnesium uptake (1.44 g $\operatorname{pot}^{-1}$ ) which was significantly higher than non-grafted $\left(0.60 \mathrm{~g} \mathrm{pot}^{-1}\right)$ and self-grafted tomato $\left(0.52 \mathrm{~g} \mathrm{pot}^{-1}\right)$. 
Table.1 Influence of INM practices of grafted tomato on nitrogen concentration (\%) in fruit, post-harvest sample and total N uptake

\begin{tabular}{|c|c|c|c|c|c|c|c|c|c|c|c|c|}
\hline \multirow[t]{2}{*}{ Treatment } & \multicolumn{4}{|c|}{ Nitrogen $(\%)$ in fruit sample } & \multicolumn{4}{|c|}{ Nitrogen $(\%)$ in post-harvest sample } & \multicolumn{4}{|c|}{ Total Nitrogen uptake $\left(\mathrm{g} \mathrm{pot}^{-1}\right)$} \\
\hline & GT & NGT & SGT & Mean $\mathbf{T}$ & GT & NGT & SGT & Mean T & GT & NGT & SGT & Mean T \\
\hline $\mathbf{T}_{1}$ (control) & 2.30 & 3.60 & 2.48 & 2.78 & 2.1 & 2.1 & 1.8 & 2.00 & 2.64 & 2.56 & 1.57 & 2.26 \\
\hline $\mathbf{T}_{2}(\mathbf{1 0 0} \%$ I.N $)$ & 3.43 & 5.90 & 3.56 & 4.30 & 3.6 & 2.87 & 2.8 & 3.09 & 5.88 & 3.75 & 2.77 & 4.13 \\
\hline $\mathrm{T}_{3}(75 \% \mathrm{I} . \mathrm{N}+25 \%$ O.N $)$ & 3.23 & 5.40 & 2.80 & 3.54 & 2.5 & 2.86 & 2.7 & 2.68 & 5.04 & 3.76 & 2.38 & 3.73 \\
\hline $\mathrm{T}_{4}(50 \%$ I.N $+50 \%$ O.N $)$ & 2.91 & 5.10 & 2.54 & 3.51 & 2.4 & 2.60 & 2.6 & 2.53 & 5.29 & 3.67 & 2.34 & 3.76 \\
\hline $\mathrm{T}_{5}(25 \%$ I.N + $75 \%$ O.N $)$ & 2.61 & 4.65 & 2.34 & 3.20 & 2.6 & 2.40 & 2.5 & 2.50 & 5.63 & 3.72 & 2.39 & 3.51 \\
\hline $\mathrm{T}_{6}(100 \% \mathrm{O} . \mathrm{N})$ & 2.73 & 3.61 & 2.14 & 2.83 & 2.4 & 2.30 & 2.6 & 2.43 & 4.73 & 3.33 & 2.31 & 3.45 \\
\hline \multirow[t]{2}{*}{ Mean B } & 2.73 & 4.70 & 2.64 & & 2.60 & 2.52 & 2.50 & & 4.83 & 3.56 & 2.34 & \\
\hline & $\mathbf{T}$ & B & $\mathbf{T} \times \mathbf{B}$ & & $\mathbf{T}$ & B & $\mathbf{T} \times \mathbf{B}$ & & $\mathbf{T}$ & B & $\mathbf{T} \times \mathbf{B}$ & \\
\hline $\operatorname{SE}(\mathbf{m})( \pm)$ & 0.17 & 0.12 & 0.30 & & 0.032 & 0.023 & 0.056 & & 0.19 & 0.13 & 0.33 & \\
\hline C. D. (0.05) & 0.51 & 0.36 & N/A & & 0.093 & 0.066 & 0.161 & & 0.55 & 0.40 & N/A & \\
\hline
\end{tabular}

- I.N- Inorganic nitrogen, O.N- Organic nitrogen

Table.2 Influence of INM practices of grafted tomato on phosphorus concentration (\%) in fruit, plant sample and total P uptake

\begin{tabular}{|c|c|c|c|c|c|c|c|c|c|c|c|c|}
\hline \multirow[t]{2}{*}{ Treatment } & \multicolumn{4}{|c|}{ Phosphorus (\%) in fruit sample } & \multicolumn{4}{|c|}{ Phosphorus (\%) in plant sample } & \multicolumn{4}{|c|}{ Total Phosphorus uptake (g pot $\left.{ }^{-1}\right)$} \\
\hline & GT & NGT & SGT & Mean T & GT & NGT & SGT & Mean T & GT & NGT & SGT & Mean T \\
\hline $\mathbf{T}_{1}($ control $)$ & 0.24 & 0.17 & 0.23 & 0.21 & 0.17 & 0.17 & 0.14 & 0.17 & 0.25 & 0.15 & 0.14 & 0.18 \\
\hline$T_{2}(100 \%$ I.N $)$ & 0.43 & 0.40 & 0.36 & 0.39 & 0.21 & 0.19 & 0.20 & 0.19 & 0.56 & 0.32 & 0.27 & 0.38 \\
\hline $\mathrm{T}_{3}(75 \%$ I.N + $25 \%$ O.N $)$ & 0.38 & 0.50 & 0.34 & 0.40 & 0.24 & 0.22 & 0.21 & 0.20 & 0.66 & 0.37 & 0.27 & 0.43 \\
\hline $\mathrm{T}_{4}(\mathbf{5 0} \%$ I.N + $50 \%$ O.N $)$ & 0.46 & 0.38 & 0.50 & 0.44 & 0.30 & 0.24 & 0.22 & 0.25 & 0.81 & 0.33 & 0.46 & 0.53 \\
\hline $\mathrm{T}_{5}(25 \%$ I.N $+75 \%$ O.N $)$ & 0.35 & 0.49 & 0.40 & 0.41 & 0.20 & 0.20 & 0.19 & 0.20 & 0.70 & 0.28 & 0.26 & 0.41 \\
\hline $\mathrm{T}_{6}(100 \% \mathrm{O.N})$ & 0.37 & 0.35 & 0.47 & 0.39 & 0.17 & 0.15 & 0.14 & 0.18 & 0.56 & 0.24 & 0.27 & 0.36 \\
\hline \multirow[t]{2}{*}{ Mean B } & 0.37 & 0.38 & 0.38 & & 0.20 & 0.17 & 0.20 & & 0.59 & 0.28 & 0.28 & \\
\hline & $\mathbf{T}$ & B & $\mathbf{T} \times \mathbf{B}$ & & $\mathbf{T}$ & B & $\mathbf{T} \times \mathbf{B}$ & & $\mathbf{T}$ & B & $\mathbf{T} \times \mathbf{B}$ & \\
\hline $\mathrm{SE}(\mathbf{m})( \pm)$ & 0.01 & 0.01 & 0.02 & & 0.004 & 0.003 & 0.008 & & 0.02 & 0.01 & 0.04 & \\
\hline C. D. (0.05) & 0.04 & 0.03 & 0.07 & & 0.009 & 0.006 & 0.016 & & 0.06 & 0.05 & 0.11 & \\
\hline
\end{tabular}

- I.N- Inorganic nitrogen, O.N- Organic nitrogen 
Table.3 Influence of INM practices of grafted tomato on Potassium concentration (\%) in fruit, plant sample and total K uptake

\begin{tabular}{|c|c|c|c|c|c|c|c|c|c|c|c|c|}
\hline \multirow[t]{2}{*}{ Treatment } & \multicolumn{4}{|c|}{ Potassium (\%) in fruit sample } & \multicolumn{4}{|c|}{ Potassium (\%) in plant sample } & \multicolumn{4}{|c|}{ Potassium uptake $\left(\mathrm{g} \mathrm{pot}^{-1}\right)$} \\
\hline & GT & NGT & SGT & Mean T & GT & NGT & SGT & Mean T & GT & NGT & SGT & Mean T \\
\hline $\mathbf{T}_{1}($ control $)$ & 1.90 & 2.13 & 1.90 & 1.96 & 1.60 & 1.04 & 1.21 & 1.28 & 1.94 & 1.54 & 1.19 & 1.56 \\
\hline $\mathrm{T}_{2}(\mathbf{1 0 0} \%$ I.N $)$ & 2.63 & 3.70 & 2.40 & 2.90 & 3.84 & 2.67 & 1.97 & 2.72 & 4.55 & 2.92 & 2.85 & 3.44 \\
\hline$T_{3}(75 \%$ I.N + $25 \%$ O.N) & 2.56 & 3.05 & 2.90 & 2.83 & 3.82 & 2.35 & 1.81 & 2.63 & 4.46 & 2.76 & 2.36 & 3.24 \\
\hline $\mathrm{T}_{4}(50 \%$ I.N $+50 \%$ O.N $)$ & 2.51 & 2.85 & 2.85 & 2.74 & 3.42 & 2.24 & 1.83 & 2.30 & 4.46 & 2.84 & 2.41 & 3.23 \\
\hline $\mathrm{T}_{5}(25 \%$ I.N + $75 \%$ O.N $)$ & 2.70 & 2.42 & 2.91 & 2.67 & 2.60 & 1.75 & 1.62 & 2.00 & 4.42 & 2.80 & 2.34 & 3.19 \\
\hline $\mathrm{T}_{6}(100 \%$ O.N $)$ & 2.36 & 2.44 & 2.90 & 2.56 & 1.93 & 1.24 & 1.54 & 1.74 & 4.04 & 2.50 & 2.17 & 2.90 \\
\hline \multirow[t]{2}{*}{ Mean B } & 2.44 & 2.76 & 2.66 & & 2.80 & 1.91 & 1.64 & & 3.98 & 2.63 & 2.24 & \\
\hline & $\mathbf{T}$ & B & $\mathbf{T} \times \mathbf{B}$ & & $\mathbf{T}$ & B & $\mathbf{T} \times \mathbf{B}$ & & $\mathbf{T}$ & B & $\mathbf{T} \times \mathbf{B}$ & \\
\hline $\mathrm{SE}(\mathbf{m})( \pm)$ & 0.22 & 0.15 & 0.38 & & 0.008 & 0.006 & 0.014 & & 0.10 & 0.07 & 0.17 & \\
\hline C. D. $(0.05)$ & 0.64 & N/A & N/A & & 0.024 & 0.017 & 0.041 & & 0.30 & 0.21 & 0.50 & \\
\hline
\end{tabular}

- I.N- Inorganic nitrogen, O.N- Organic nitrogen

Table.4 Influence of INM practices of grafted tomato on Calcium concentration (\%) in fruit, plant sample and total Ca uptake

\begin{tabular}{|c|c|c|c|c|c|c|c|c|c|c|c|c|}
\hline \multirow[t]{2}{*}{ Treatment } & \multicolumn{4}{|c|}{ Calcium (\%) in fruit sample } & \multicolumn{4}{|c|}{ Calcium (\%) in plant sample } & \multicolumn{4}{|c|}{ Calcium uptake $\left(\mathrm{g} \mathrm{pot}^{-1}\right)$} \\
\hline & GT & NGT & SGT & Mean T & GT & NGT & SGT & Mean T & GT & NGT & SGT & $\begin{array}{c}\text { Mean } \\
\mathbf{T}\end{array}$ \\
\hline $\mathbf{T}_{1}$ (control) & 0.66 & 0.57 & 0.57 & 0.60 & 1.91 & 1.52 & 1.91 & 1.80 & 1.30 & 1.03 & 0.74 & 1.02 \\
\hline $\mathrm{T}_{2}(100 \% \mathrm{I} . \mathrm{N})$ & 0.80 & 0.96 & 0.64 & 0.80 & 3.11 & 1.80 & 2.16 & 2.35 & 2.50 & 1.35 & 1.73 & 1.86 \\
\hline$T_{3}(75 \%$ I.N + $25 \%$ O.N $)$ & 1.24 & 1.10 & 0.63 & 0.99 & 2.74 & 2.94 & 1.80 & 2.50 & 2.65 & 1.53 & 1.42 & 1.87 \\
\hline $\mathrm{T}_{4}(50 \%$ I.N $+50 \%$ O.N $)$ & 1.04 & 1.15 & 0.70 & 0.96 & 2.73 & 2.34 & 2.54 & 2.54 & 2.35 & 1.86 & 1.70 & 1.97 \\
\hline $\mathrm{T}_{5}(25 \% \mathrm{I} . \mathrm{N}+75 \%$ O.N $)$ & 1.08 & 1.40 & 0.72 & 1.06 & 2.54 & 2.60 & 2.73 & 2.62 & 2.60 & 1.67 & 1.67 & 1.98 \\
\hline $\mathrm{T}_{6}(100 \%$ O.N $)$ & 1.46 & 1.43 & 0.93 & 1.19 & 3.13 & 3.11 & 2.15 & 2.80 & 2.63 & 1.62 & 1.77 & 2.01 \\
\hline Mean B & 1.04 & 1.10 & 0.66 & & 2.70 & 2.50 & 2.11 & & 2.34 & 1.51 & 1.50 & \\
\hline & $\mathbf{T}$ & B & $\mathbf{T} \times \mathbf{B}$ & & $\mathbf{T}$ & B & $\mathbf{T} \times \mathbf{B}$ & & $\mathbf{T}$ & B & $\mathbf{T} \times \mathbf{B}$ & \\
\hline $\mathrm{SE}(\mathrm{m})( \pm)$ & 0.08 & 0.05 & 0.14 & & 0.01 & 0.006 & 0.013 & & 0.09 & 0.06 & 0.16 & \\
\hline C. D. (0.05) & 0.22 & 0.16 & N/A & & 0.022 & 0.016 & 0.04 & & 0.26 & 0.19 & 0.46 & \\
\hline
\end{tabular}

I.N- Inorganic nitrogen, O.N- Organic nitrogen 
Table.5 Influence of INM practices of grafted tomato on Magnesium concentration (\%) in fruit, post-harvest sample and total Mg uptake

\begin{tabular}{|c|c|c|c|c|c|c|c|c|c|c|c|c|}
\hline \multirow[t]{2}{*}{ Treatment } & \multicolumn{4}{|c|}{ Magnesium (\%) in fruit sample } & \multicolumn{4}{|c|}{ Magnesium (\%) in plant sample } & \multicolumn{4}{|c|}{ Magnesium uptake $\left(\mathrm{g} \mathrm{pot}^{-1}\right)$} \\
\hline & GT & NGT & SGT & Mean T & GT & NGT & SGT & Mean T & GT & NGT & SGT & $\begin{array}{c}\text { Mean } \\
\mathbf{T}\end{array}$ \\
\hline $\mathbf{T}_{1}($ control) & 0.18 & 0.15 & 0.25 & 0.19 & 0.23 & 0.12 & 0.11 & 0.15 & 0.21 & 0.17 & 0.14 & 0.17 \\
\hline $\mathrm{T}_{2}(100 \% \mathrm{I} . \mathbf{N})$ & 0.70 & 0.41 & 0.67 & 0.59 & 0.61 & 0.50 & 0.83 & 0.41 & 0.88 & 0.53 & 0.33 & 0.58 \\
\hline$T_{3}(75 \%$ I.N + $25 \%$ O.N) & 0.47 & 0.47 & 0.59 & 0.60 & 0.50 & 0.70 & 0.12 & 0.68 & 1.21 & 0.41 & 0.63 & 0.75 \\
\hline $\mathrm{T}_{4}(50 \%$ I.N + $50 \%$ O.N $)$ & 0.70 & 0.70 & 0.77 & 0.72 & 0.95 & 1.13 & 0.38 & 0.82 & 1.48 & 0.87 & 0.51 & 0.95 \\
\hline $\mathbf{T}_{5}(25 \%$ I.N + $75 \%$ O.N $)$ & 0.67 & 1.08 & 0.50 & 0.75 & 1.26 & 1.04 & 0.51 & 0.93 & 2.21 & 0.72 & 0.57 & 1.17 \\
\hline $\mathbf{T}_{6}(100 \%$ O.N $)$ & 0.56 & 1.26 & 0.70 & 0.83 & 1.50 & 0.95 & 1.3 & 1.25 & 2.62 & 0.90 & 0.67 & 1.39 \\
\hline \multirow[t]{2}{*}{ Mean B } & 0.56 & 0.71 & $\mathbf{0 . 5 0}$ & & 0.84 & 0.74 & 0.54 & & 1.44 & 0.60 & 0.52 & \\
\hline & $\mathbf{T}$ & B & $\mathbf{T} \times \mathbf{B}$ & & $\mathbf{T}$ & B & $\mathbf{T} \times \mathbf{B}$ & & $\mathbf{T}$ & B & $\mathbf{T} \times \mathbf{B}$ & \\
\hline $\operatorname{SE}(\mathbf{m})( \pm)$ & 0.06 & 0.04 & 0.01 & & 0.01 & 0.01 & 0.02 & & 0.08 & 0.05 & 0.13 & \\
\hline C. D. (0.05) & 0.16 & 0.11 & 0.28 & & 0.03 & 0.020 & 0.05 & & 0.22 & 0.16 & 0.40 & \\
\hline
\end{tabular}

I.N- Inorganic nitrogen, O.N- Organic nitrogen

Table.6 Influence of INM practices of grafted tomato on Sulphur concentration (\%) in fruit, plant sample and total S uptake

\begin{tabular}{|c|c|c|c|c|c|c|c|c|c|c|c|c|}
\hline \multirow[t]{2}{*}{ Treatment } & \multicolumn{4}{|c|}{ Sulphur (\%) in fruit sample } & \multicolumn{4}{|c|}{ Sulphur (\%) in plant sample } & \multicolumn{4}{|c|}{ Sulphur uptake $\left(\mathrm{g} \mathrm{pot}^{-1}\right)$} \\
\hline & GT & NGT & SGT & Mean T & GT & NGT & SGT & Mean T & GT & NGT & SGT & Mean T \\
\hline $\mathbf{T}_{1}$ (control) & 0.12 & 0.11 & 0.11 & 0.11 & 0.14 & 0.12 & 0.12 & 0.12 & 0.17 & 0.12 & 0.10 & 0.13 \\
\hline $\mathrm{T}_{2}(100 \%$ I.N $)$ & 0.25 & 0.22 & 0.24 & 0.24 & 0.21 & 0.19 & 0.18 & 0.19 & 0.49 & 0.24 & 0.27 & 0.33 \\
\hline $\mathrm{T}_{3}(75 \%$ I.N + $25 \%$ O.N $)$ & 0.40 & 0.37 & 0.24 & 0.34 & 0.23 & 0.20 & 0.16 & 0.20 & 0.70 & 0.29 & 0.22 & 0.40 \\
\hline $\mathrm{T}_{4}(50 \%$ I.N $+50 \%$ O.N $)$ & 0.44 & 0.45 & 0.34 & 0.41 & 0.22 & 0.22 & 0.20 & 0.21 & 0.73 & 0.31 & 0.26 & 0.43 \\
\hline $\mathrm{T}_{5}(25 \%$ I.N $+75 \%$ O.N $)$ & 0.51 & 0.37 & 0.39 & 0.48 & 0.24 & 0.22 & 0.19 & 0.21 & 0.78 & 0.26 & 0.27 & 0.43 \\
\hline $\mathbf{T}_{6}(100 \%$ O.N $)$ & 0.35 & 0.30 & 0.33 & 0.52 & 0.24 & 0.21 & 0.21 & 0.22 & 0.76 & 0.30 & 0.28 & 0.44 \\
\hline Mean B & 0.34 & 0.30 & 0.27 & & 0.22 & 0.20 & 0.19 & & 0.57 & 0.24 & 0.22 & \\
\hline & $\mathbf{T}$ & B & $\mathbf{T} \times \mathbf{B}$ & & $\mathbf{T}$ & B & $\mathbf{T} \times \mathbf{B}$ & & $\mathbf{T}$ & B & $\mathbf{T} \times \mathbf{B}$ & \\
\hline SE(m) ( $( \pm)$ & 0.003 & 0.002 & 0.005 & & 0.002 & 0.001 & 0.003 & & 0.02 & 0.01 & 0.04 & \\
\hline C. D. (0.05) & 0.01 & 0.01 & 0.02 & & 0.004 & 0.003 & 0.01 & & 0.06 & 0.04 & 0.10 & \\
\hline
\end{tabular}

I.N- Inorganic nitrogen, O.N- Organic nitrogen 


\section{Sulphur}

The INM packages resulted in highest content of sulphur in $\mathrm{T}_{6}$ in fruit $(0.52 \%)$, plant $(0.22 \%)$ and total $\mathrm{P}$ uptake $\left(0.44 \mathrm{~g} \mathrm{pot}^{-1}\right)$ which were significantly higher than control (Table 6). The results showed that $\mathrm{S}$ concentration and uptake was decreasing with incremental proportion of inorganic nutrients. Application of organic manures improved $\mathrm{S}$ concentration and uptake in tomato. These improvements primarily seen to be on account of enrichment of soil by these nutrients. Secondarily it can be attributed to their efficient extraction or translocation due to increase in root ramification or activities as organic manures plays vital role in maintaining better physicochemical and biological properties of soils. The results indicating better nutritional status of plant with organic fertilization are in close conformity with findings of Singh and Tomar (1991).

Out of three types of grafted tomatoes, the Grafted tomato recorded highest content of sulphur in fruit $(0.34 \%)$ and plant $(0.22 \%)$ which was $17.9,15.8$ per cent and 32,10 per cent more over non-grafted and self-grated tomato respectively. While in total S uptake Grafted tomato resulted in highest sulphur uptake $\left(0.57 \mathrm{~g} \mathrm{pot}^{-1}\right)$ which was significantly higher than non-grafted $\left(0.24 \mathrm{~g} \mathrm{pot}^{-1}\right)$ and self-grafted tomato $\left(0.22 \mathrm{~g} \mathrm{pot}^{-1}\right)$. The grafted tomato showed 130 per cent and 140 per cent more uptake over non-grafted and self-grafted tomatoes respectively.

Mineral nutrients are usually obtained from the soil through plant roots, but many factors can affect the efficiency of nutrient acquisition. The chemistry and composition of certain soils can make it harder for plants to absorb nutrients. Some plants possess mechanisms or structural features that provide advantages when growing in certain types of nutrient limited soils. In fact, most plants have evolved nutrient uptake mechanisms that are adapted to their native soils and are initiated in an attempt to overcome nutrient limitations. One of the most universal adaptations to nutrient-limited soils is a change in root structure that may increase the overall surface area of the root to increase nutrient acquisition or may increase elongation of the root system to access new nutrient sources. These changes can lead to an increase in the allocation of nutrients to overall root growth, thus resulting in greater root to shoot ratios in nutrient-limited plants (Lopez-Bucio et al., 2003).Rootstocks with high specific root length (SRL) and a greater root length, density were able to extract water more rapidly and also take up inorganic nutrients including nitrate more efficiently, in contrast to those with low SRL. With these root traits of the rootstocks in grafted tomato plants, there was an increase in absorption, translocation and accumulation of nutrients in the scion particularly in brinjal grafted tomato. Similar results obtained by Ruiz and Romero (1999). The positive influence of rootstocks on the nutrient contents of the aboveground plant tissues may depend upon the physical characteristics of the root system, such as more root density, more number of root hairs, lateral and vertical development of roots which increased the absorption and translocation of nutrients. This may be directly linked to the increased growth and development by grafted plants (Lee, 1994; Martínez-Ballesta et al., 2010). The results corroborated by earlier findings of Davis et al., (2008), Lee (1994), Ruiz and Romero (1999), Leonardi and Giuffrida (2006), Martinez-Ballesta et al., (2010), Colla et al., (2011), Lee and Oda (2003), Desire Djionou (2012).

This study shows that grafted tomato has shown more nutrient concentration and uptake compared to non-grafted and self-grafted 
tomato in all INM packages. Irrespective of grafting method, the treatment $100 \%$ inorganic nitrogen showed highest $\mathrm{N}$ and $\mathrm{K}$ concentration and uptake. where as the treatment $100 \%$ organic nitrogen showed highest $\mathrm{Ca}, \mathrm{Mg}$ and $\mathrm{S}$ concentration and uptake, But $\mathrm{P}$ concentration and uptake was highest in combination of inorganic and organic treatments. We can conclude that for maintain soil health grafted tomato with incremental proportion of organic nutrients is the best.

\section{References}

A.O.A.C. 1960. Official methods of Analysis. Association of Official Agricultural Chemists $\left(10^{\text {th }}\right.$ edition) Washington D.C.

Asik BB, Turan MA, Celik H and Katkat AV. 2009. Effect of Humic Substances to Dry Weight and Mineral Nutrients Uptake of Wheat on Saline Soil Conditions, Asian Journal of Crop Science, 1(2): 87-95.

Azam S, Shah WM, Syed MS, Muhammad SS (2013). Effect of Organic and Chemical Nitrogen Fertilizers on Grain Yield and Yield Components of Wheat and Soil Fertility. Sci. J. Agron. Plant Breeding. 1(2):37-48.

Chapman HD. 1965. Methods of Soil Analysis, Part-II, American Society of Agronomy, Inc. Wisconsin, USA: 891900.

Colla, G., Rouphael, Y., Mirabelli, C., Cardarelli, M., 2011. Nitrogen-use efficiency traits of mini-watermelon in response to grafting and nitrogenfertilization doses. Journal of Plant Nutrition and Soil Science174, 933-941.

Crinò, P., Lo Bianco, C., Rouphael, Y., Colla, G., Saccardo, F., Paratore, A., 2007. Evaluation of rootstocks resistance to fusarium wilt and gummy stem blight and effect on yield and quality of a grafted in odorous melon. Horticultural Science, 42: 521-525.

Davis A, Perkins PV, Sakata Y, Galarza SL,
Maroto, JV, Lee SG, Huh YC, Sun Z, Miguel A, King S, Cohen R and Lee JM. 2008. Cucurbit grafting, Critical Reviews in Plant Science, 27(1): 50-74.

Djidonou D. 2012. Improving fruit yield and nutrient management in tomato production by using grafting. A dissertation presented to the graduate school of the University of Florida in partial fulfilment of the requirements for the degree of Doctor of Philosophy, University of Florida.

Ghosh K, Chowdhury MAH, Rahman MH, Bhattacherjee S (2014). Effect of integrated nutrient management on nutrient uptake and economics of fertilizer use in rice cv. NERICA 10. Journal of Bangladesh Agricultural University. 12(2): 273-277.

Gomez, K.A. and Gomez, A.A.(1984) Statistical procedures for agricultural research (2 ed.). John Wiley and Sons,New York.

Heitkamp F, Raupp J and Ludwig B. 2011. Soil Organic Matter Pools and Crop Yields as Affected by the Rate of Farmyard Manure and Use of Biodynamic Preparations in a Sandy Soil, Organic Agriculture, 1: 111-124.

Kachot N.A, Malaviya D.D, Solanki R.M and Sagarka B.K. 2001. Integrated nutrient management in rainy season groundnut (Arachis hypogea) and soil properties. Indian Journal of Agricultural Sciences75(4):218-221.

King S, Davis A, Zhang X and Crosby K. 2010. Genetics, breeding and selection of rootstocks for solanaceae and cucurbitaceae, Scientia Horticulturae. 127(2): 106-111.

Lee $\mathbf{J}$ and Oda M. 2003. Grafting of herbaceous vegetable and ornamental crops, Horticultural Reviews, 28: 61-124.

Lee J. 1994. Cultivation of grafted vegetables. I. Current status, grafting methods, and benefits, Horticultural Science, 29(4): 235-239. 
Lee JM, Kubota C, Tsao S, Bie Z, Echevarria PH, Morra L and Oda M. 2010. Current status of vegetable grafting: Diffusion, grafting techniques, automation, Scientia Horticulturae, 127(2): 93-105.

Leonardi C and Giuffrida F. 2006. Variation of plant growth and macronutrient uptake in grafted tomatoes and eggplants on three different rootstocks, European Journal of Horticultural Science, 71(3) 97-101.

Lopez-Bucio J. et al., The role of nutrient availability in regulating root architecture. Current Opinion in Plant Biology, 6, 280287 (2003).

Lynch, D.H., Voroney, R.P., and Warman, P.R. (2004). Nitrogen availability from composts for humid region perennial grass and legume-grass forage production. Journal of Environmental Quality. 33:1509-1520.

Martínez-Ballesta, C.M., Alcaraz-López, C., Muries, B., Mota-Cadenas, C., Carvajal, M., 2010. Physiological aspects of rootstock-scion interactions. Scientia Horticulturae, 127, 112-118.

Munroe G. 2007. Manual of On-Farm Vermicomposting and Vermiculture, Publication of Organic Agriculture Centre of Canada, Nova Scotia.

Najar IA and Khan AB. 2013. Management of Fresh Water Weeds (Macrophytes) by Vermicomposting Using Eisenia foetida, Environmental Science and Pollution Research, 20(9): 6406-6417.

Page AL, Miller RH and Keeney DR.1982. Methods of soil analysis-part 2. Chemical and microbiological properties, $2^{\text {nd }}(\mathrm{Ed})$ No. 9, Agronomy series ASA-SSSA publishers, Madison Wisconsin, USA.

Piper CS. 1950. Soil and plant analysis.
Academi Press, New York.

Proietti, S., Y. Rouphael, G. Colla, M. Cardarelli, M. De Agazio, M. Zacchini, E. Rea, S. Moscatello, and A. Battistelli. 2008. Fruit quality of mini watermelon as affected by grafting and irrigation regimes. J. Sci. Food Agri., ,88: 11071114.

Pyo Y. J. et al., High Affinity K+ Transport in Arabidopsis: AtHAK5 and AKT1 are Vital for Seedling Establishment and Postgermination Growth under LowPotassium Conditions. Plant Physiology. 153, 863-875 (2010).

Rivard CL, O'Connell S, Peet M and Louws F. 2010a. Grafting tomato with interspecific rootstock to manage diseases caused by Sclerotium rolfsii and southern root-knot nematode, Plant Disease, 94(8): 1015-1021.

Rouphael Y, Cardarelli M, Colla G and ReaE. 2008b. Yield, mineral composition, water relations, and water use efficiency of grafted mini-watermelon plants under deficit irrigation, Horticultural Science, 43(3): 730-736.

Ruiz J and Romero L. 1999. Nitrogen efficiency and metabolism in grafted melon plants, Scientia Horticulturae, 81(2): 113-123.

Singh, V. and Tomar, J.S. 1991. Effect of K and FYM levels on yield and uptake of nutrient by wheat. Journal of Potassium Research. 7(4): 309-312.

Verma, L. N. and Rawat, A. K. 1999. Low grade rock phosphate a complimentary phosphorus source in soybean (Glycine max) and wheat (Triticum aestivum) cropping system. Indian Journal Agriculture Science, 69(4): 297-299.

\section{How to cite this article:}

Kiran Pilli, P.K. Samant, P. Naresh and Acharya, G.C. 2019. Effect of Integrated Nutrient Management on Nutrient concentration and Uptake in Grafted Tomato. Int.J.Curr.Microbiol.App.Sci. 8(02): 1580-1590. doi: https://doi.org/10.20546/ijcmas.2019.802.185 